\title{
PENGARUH PERMAINAN BAKIAK TERHADAP PERKEMBANGAN SOSIAL ANAK KELOMPOK B (USIA 5-6 TAHUN) DI TK NUSA INDAH PALEMBANG
}

\author{
Arini Mayang Fauni ${ }^{1}$, Dr. H. Bukman Lian, M.M., M.Si. ${ }^{2}$, \\ Rahmah Novianti. S.Sos., M.Pd. ${ }^{3}$ \\ Email: faunimayang2@gmail.com ${ }^{1}$,dr.bukmanlian@gmail.com² \\ aliciarahmah@gmail.com ${ }^{3}$
}

\begin{abstract}
Abstrak: Penelitian ini bertujuan untuk mengetahui ada atau tidaknya pengaruh permainan bakiak terhadap perkembangan sosial anak kelompok B (usia 5-6 tahun) Di TK Nusa Indah Palembang. Dalam penelitian ini menggunakan penelitian' kuantitatif dengan metode eksperimen, desain yang digunakan dalam penelitian ini adalah true eksperimental design dengan bentuk desain pretest-posttest control group design. Populasi penelitian adalah anak kelompok B di TK Nusa Indah palembang. Sampel penelitian adalah kelas B2 dengan jumlah 16 orang anak. Teknik pengumpulan data yang digunakan yaitu observasi dan dokumentasi dengan analisis data menggunakan uji-t. Berdasarkan hasil penelitian postest dan pretest yang dihitung dengan menggunakan uji-t diperoleh nilai $t_{\text {hitung }}=6,1$ dan $t_{\text {table }}=2,42$ dapat disimpulkan bahwa $t_{\text {hitung }}>t_{\text {table }}$ atau 6,1> 2,42 maka $\mathrm{H}_{0}$ ditolak dan $\mathrm{H}_{\mathrm{a}}$ diterima. Yang artinya terdapat pengaruh yang signifikan dari permainan bakiak terhadap perkembangan sosial anak usia dini kelompok B di TK Nusa Indah Palembang.
\end{abstract}

Kata kunci : Permainan Bakiak, Perkembangan Sosial

\section{PENDAHULUAN}

Pendidikan merupakan suatu proses pembelajaran pengetahuan, keterampilan guna membantu manusia dalam pertumbuhan dan perkembangannya melalui pengajaran dan pelatihan. Dengan adanya pendidikan maka peserta didik dapat memiliki akhlak mulia, kecerdasan, kepribadian, keterampilan, dan banyak hal lainnya yang akan bermanfaat bagi dirinya sendiri maupun di masyarakat kelak. Oleh karena itu pendidikan sangat penting bagi setiap manusia untuk menjadi acuan atau pedoman agar memiliki pemahaman terhadap sesuatu dan membuatnya menjadi seseorang yang kritis dalam berfikir maupun bertindak. Maka dari itu pendidikan harus dimulai sejak dini sehingga dapat mempersiapkan dengan matang dan menghasilkan sumber daya yang unggul.

$$
\text { Pendidikan Anak Usia Dini }
$$
merupakan tanggung jawab bersama antara guru, keluarga, masyarakat, dan pemerintah. Lembaga Pendidikan Anak Usia Dini sebagai pembantu kelanjutan pendidikan anak setelah keluarganya, karena keluarga terutama orang tua mempunyai kewajiban untuk mengasuh anak-anaknya dengan memelihara, membimbing, dan mengarahkannya. Maka dari itu lembaga pendidikan anak usia dini berperan penting dalam ikut serta membantu anak dalam bertumbuh dan 
berkembang untuk mengembangkan seluruh aspek yang ada dalam diri anak yaitu dengan cara menstimulus.

Salah satu cara yang dilakukan untuk menstimulus anak yaitu dengan melalui metode bermain karena bermain mempunyai manfaat bagi perkembangan anak yaitu sebagai pengalaman belajar yang sangat berguna untuk anak, dan bermain juga mengandung unsur-unsur yang bersifat mendidik. Salah satu permainan yang dapat menstimulus perkembangan anak yaitu permainan bakiak.

Permainan bakiak merupakan salah satu permainan tradisional yang berasal dari Sumatera Barat yang dilahirkan pertengahan tahun 1970-an. Alat permainan ini terbuat dari dua papan kayu tebal berbentuk sandal yang panjangnya sekitar $125 \mathrm{~cm}$. Pada masing-masing papan terdapat tiga atau empat tali karet untuk pengikat kaki pemain. Permainan ini dilakukan dengan cara berkelompok yang mana tiap kelompok terdiri atas tiga atau empat orang anak. Setiap anak harus memasukkan kakinya ke dalam lekukan tali yang telah terpasang pada sepasang kayu panjang tersebut. Kemudian anak berjalan dengan menggunakan sepasang kayu tersebut hingga mencapai garis finish. Dalam permainan ini anak dituntut untuk saling berkomunikasi, bekerjasama dalam tiap kelompok agar mampu tiba digaris finish dengan cepat. Karena dengan melakukan permainan bakiak anak dapat mengembangkan salah satu aspek yakni aspek perkembangan sosial anak,

Dalam hal ini, salah satu aspek perkembangan yang sangat penting bagi anak usia dini adalah perkembangan sosial, karena perkembangan sosial adalah penentu bagaimana anak nantinya bersosialisasi di lingkungan sosialnya. Perkembangan sosial merupakan perkembangan tingkah laku anak dalam menyesuaikan diri dengan lingkungan sekitar termasuk aturan-aturan yang ada di lingkungan masyarakat ditempat anak itu tinggal. Melalui permaianan bakiak manfaat bagi perkembangan sosial anak yaitu memperlancar anak dalam berinteraksi, saling bekerjasama, bergaul dengan teman sebaya, memahami peraturan, membina hubungan dengan kelompok dan mengatasi konflik dalam bermain. Jadi dengan menggunakan permainan bakiak ini dapat dijadikan sebagai suatu kegiatan yang dapat membantu mengembangkan perkembangan sosial anak.

Penelitian yang dilakukan oleh Zulfauzia, dkk (2016) pada anak usia 5 -6 tahun di TK Negeri Terpadu Singkawang. 
Hasil pengukuran dari 20 anak pada siklus I pertemuan 1 sbb: kelenturan mencapai $70 \%$ belum berkembang dan $30 \%$ mulai berkembang, b) keseimbangan mencapai $35 \%$ belum berkembang dan $65 \%$ mulai berkembang, c) ketangkasan mencapai $60 \%$ belum berkembang dan $40 \%$ mulai berkembang. Kemudian mengalami peningkatan pada siklus II pertemuan $2 \mathrm{sbb}$ : a) kelenturan mencapai $45 \%$ berkembang sesuai harapan dan $55 \%$ berkembang sangat baik, b) keseimbangan $65 \%$ berkembang sesuai harapan dan 35\% berkembang sangat baik, c) ketangkasan $15 \%$ mulai berkembang, $60 \%$ berkembang sesuai harapan dan $15 \%$ berkembang sangat baik.

Berdasarkan hasil observasidengan guru di TK Nusa Indah Palembang kelompok B, beberapa anak di akui masih pasif, malu untuk berbaur dengan teman sekelasnya, selain itu anak lebih pilih-pilih dalam berteman (berkelompok). Hal ini terlihat pada saat kegiatan belajar seharihari. Ketidaklancaran anak dalam berinteraksi ini membuat anak menjadi pasif saat berada didalam kelas, saat pembelajaran berlangsung maupun saat main bersama temannya. Sehingga menjadikan anak kurang terampil dalam berinteraksi.
Berdasarkan latar belakang masalah di atas penulis bermaksud melakukan upaya untuk meningkatkan perkembangan sosial anak dalam berinteraksi dilingkungannya melalui permainan bakiak. Sehingga rumusan judul penelitian ini berjudul: "Pengaruh Permainan Bakiak Terhadap Perkembangan Sosial Pada Anak Kelompok B Usia 5-6Tahun di Tk Nusa Indah Palembang”. TINJAUAN PUSTAKA

\section{Permainan Bakiak}

Permainan adalah berbagaikegiatan yang dirancang bertujuan untuk mengembangkan beberapa kemampuan tertentu pada anak sehingga mendapatkan pengalaman-pengalaman yang menyenangkan, menimbulkan kegembiraan serta mengekspresikan apa yang anak rasakan.

Menurut Desmita (2015:141), permainan adalah salah satu bentuk aktivitas sosial yang dominan pada awal masa anak-anak. Sebab anak-anak menghabiskan lebih banyak waktunya di luar rumah bermain dengan temantemannya dibanding terlibat aktivitas lain. Karena itu, kebanyakan hubungan sosial dengan teman sebaya dalam masa ini terjadi dalam bentuk permainan. Jadi permainan bagi anak adalah suatu bentuk aktivitas 
yang menyenangkan yang dilakukan semata-mata untuk aktivitas itu sendiri, bukan karena ingin memperoleh sesuatu yang di hasilkan dari aktivitas tersebut.

Selanjutnya menurut Santrock (2007:216), permainan adalah aktivitas menyenangkan yang dilakukan untuk bersenang-senang. Selain untuk bersenangsenang permainan merupakan sarana belajar anak, melalui permainan anak dapat menemukan hal-hal baru yang sangat berguna untuk membangun pengetahuannya. Dengan permainan anak dapat mengembangkan intelektual serta mengembangkan keterampilan psikis dan sosial anak. Permainan merupakan sarana yang paling utama untuk mencapai pertumbuhan dan perkembangan anak. Jadi permainan adalah aktivitas yang menimbulkan rasa senang kepada anak karena anak dapat menemukan hal-halbaru untuk pengetahuannya dengan cara yang menyenangkan.

Sedangkan menurut Suyadi dan Ulfah (2015:34), permainan adalah sesuatu yang menyenangkan, suka rela, penuh arti, dan aktivitas spontan. Permainan sering juga dianggap kreatif, yang menyertakan pemecahan masalah, belajar keterampilan sosial, bahasa, dan keterampilan fisik. Sehingga sering disebut bahwa dunia anak adalah dunia bermain, yaitu dunia yang penuh spontanitas dan menyenangkan. Bermain mempunyai fungsi untuk membantu anak dalam mencapai perkembangan seperti keterampilan bahasa, sosial, dan fisik. Jadi permainan bagi anak adalah aktivitas yang dilakukan secara spontan, kreatif, dan belajar berbagai aspek keterampilan anak.

Berdasarkan ketiga pendapat di atas dapat disimpulkan bahwa permainan adalah keseluruhan aktivitas yang dilakukan oleh anak baik sendiri atau bersama-sama yang sifatnya menyenangkan, menggembirakan dan berfungsi untuk membantu anak dalam mengembangkan kreativitasnya. Selain itu dengan permainan ini juga dapat membantu anak sebagai sarana belajar yang mampu mengembangkan beberapa aspek yakni aspek fisik, sosial emosional, bahasa, perkembangan intelektual dan seni.

Bakiak adalah sejenis sandal yang telapaknya terbuat dari kayu yang ringan dengan pengikat kaki terbuat dari ban bekas yang dipaku kedua sisinya. Menurut Sri Mulyani (2013:9-11), bakiak atau disebut terompa galuak adalah permainan tradisional anak yang berasal dari Sumatera Barat. Bakiak terbuat dari dua papan kayu tebal berbentuk sandal yang panjangnya sekitar $125 \mathrm{~cm}$. Pada masing-masing papan terdapat tiga atau empat tali karet untuk pengikat kaki pemain. Bakiak dirancang 
sedemikian rupa agar dapat digunakan oleh tiga atau empat anak sekaligus. Hingga sekarang permainan ini cukup populer untuk mengisi lomba 17 Agustus di kampung. Permainan bakiak membutuhkan kerjasama dan kekompakan para pemainnya. Bakiak ini memerlukan tempat cukup luas dan penerangan yang cukup untuk bermain. Pada lomba biasanya terdiri dari 3 hingga 4 regu. Semakin banyak peserta akan lebih seru. Pemain bebas bisa laki-laki maupun perempuan. Jarak tempuh pada lomba antar 10 hingga 15 meter. Jadi permainan bakiak adalah permainan tradisional yang berasal dari Sumatera barat yag terbuat dari terompah kayu dengan bentul sandal memanjang yang dimainkan dengan tiga pasang orang atau lebih

Selanjutnya menurut Eci (2017:4445), Bakiak adalah permainan tradsional yang menggunakan bakiak berukuran panjang. Sepasang bakiak panjang diberi beberapa selop dari karet di atasnya. Lalu, permainan menyorongkan kaki pada masing-masing selop dan saling memegangi pemain didepannya. Permainan ini membutuhkan kekompakan tim. Tujuan permainan ini ialah berjalan seirama menuju titik akhir yang ditentukan. Sejarahnya bakiak yang bernama lain terompa galuak, ini berasal dari Sumatera barat. Bakiak termasuk salah satu permainan yang dilombakan saat perayan kemerdekaan Indonesia. Jadi permainan bakiak adalah permainan menggunakan selop kayu, cara memainkannya dengan menyorongkan kaki pada masing-masing selop dan membutuhkan kerja sama.

Sedangkan menurut Esnoesanoesi (dalam Maria 2013:198), mengatakan bahwa bakiak adalah permainan tradisional yang mengutamakan kekompakan dan kebersamaan antara para peserta. Para pemain harus berjalan secara kompak untuk menjaga keseimbangan agar tidak terjatuh. Bakiak terbuat dari kayu yang berbentuk alas kaki panjang yang dapat digunakan oleh peserta antara lima sampai enam orang. Jadi permainan bakiak adalah permaianan yang mengandalkan kekompakan untuk melakukan permainan.

Menurut ketiga pendapat di atas bakiak adalah terompa galuak yang berasal dari Sumatera Barat yang merupakan terompah deret dari papan bertali karet yang panjangnya sekitar $125 \mathrm{~cm}$. Sepasang bakiak minimal memiliki tiga pasang sandal atau dimainkan tiga anak. Pada masing-masing papan terdapat tiga atau empat tali karet untuk pengikat kaki pemain.

Jadi dapat disimpulkan bahwa permainan bakiak adalah permainan tradisional Sumatera Barat yang terbuat 
dari terompah kayu yang dilakukan tiga sampai empat orang atau lebih yang membutuhkan kerja sama/kekompakan untuk melakukan permainannya agar mencapai garis finish.

\section{Perkembangan Sosial}

Perkembangan sosial merupakan suatu kemampuan sikap atau tata cara dalam berinteraksi seseorang dengan orang lain, mulai dari orang tua, saudara, teman sebaya, hingga masyarakat secara luas.

Menurut Yusuf (2015:122), perkembangan sosial anak merupakan pencapaian kematangan hubungan sosial. Dapat juga diartikan sebagai proses belajar untuk menyesuaikan diri terhadap normanorma kelompok, moral dan tradisi, meleburkan diri menjadi suatu kesatuan yang saling berkomunikasi dan bekerja sama. Jadi perkembangan sosialmerupakan proses menyesuaikan diri terhadap lingkungan sekitar.

Selanjutnya menurut Ahmadi (dalam Suhada, 2017:103-104), perkembangan sosial merupakan peranan yang sangat penting dalam menentukan hubungan sosial di masa depan dan pola perilaku terhadap orang lain. Karena kehidupan baru berpusat di sekitar rumah, maka dirumahlah diletakkan dasar perilaku dan sikap sosialnya kelak. Jadi perkembangan sosial adalah yang berperan penting dalam proses menentukan hubungan sosial manusia dan pola perilaku terhadap orang lain.

Sedangkan menurut Fakhrudin (dalam Mulyani, 2016:111), perkembangan sosial adalah suatu proses yang muncul di mana anak-anak belajar tentang diri dan tentang membangun dan merawat pertemanan. Perkembangan sosial dimulai pada saat lahir dan muncul dari interaksi yang di alami bayi dan anak kecil di rumah dan selanjutnya bersosialisasi di luar rumah. Jadi perkembangan sosial adalah proses anak belajar membangun pertemanan dan perkembangan sosial dimulai sejak bayi baru lahir.

Berdasarkan beberapa pendapat di atas dapat disimpulkan bahwa perkembangan sosial adalah proses belajar menyesuaikan diri dengan lingkungan untuk menentukan hubungan sosial manusia terhadap norma-norma kelompok, moral dan tradisi, dengan cara berinterkasi sehingga menjadi suatu kesatuan yang saling beradaptasi.ETODOLOGI

\section{PENELITIAN}

Menurut Sugiyono (2017:61), variabel penelitian adalah suatu atribut atau sifat atau nilai dari orang, obyek atau kegiatan yang mempunyai variasi tertentu yang ditetapkan oleh peneliti untuk dipelajari dan kemudian ditarik 
kesimpulannya. Dalam penelitian ini terdapat dua variabel yaitu variabel bebas (X) dan variabel terikat (Y). Variabel bebas (X) dalam penelitian ini yaitu permainan bakiak, sedangkan variabel terikat (Y) dalam penelitian ini yaitu perkembangan sosial.

Penelitian ini akan dilakukan di TK Nusa Indah Palembang. Peneliti memilih TK Nusa Indah Palembang yang beralamat di Jalan Kenari I No 1180 Palembang. Dengan memiliki kelas yang teridiri kelompok dari B1 B2 B3 B4 dengan jumlah siswa. Peneliti mem ilih TK Nusa Indah sebagai tempat penelitian. Penelitian ini dilaksanakan pada semester genap tahun ajaran 2019/2020. Metode yang digunakan dalam penelitian ini adalah eksperimen dengan menggunakan true eksperimental design dengan bentuk desain pretestposttest control group design.

Teknik pengumpulan data yang digunakan dalam penelitian ini yaitu observasi dan dokumentasi. Uji hipotesis dilakukan untuk mengetahui ada tidaknya pengaruh dan signifikan dari permainan baiak terhadap perkembangan sosial anak pada kelompok B TK Nusa Indah Palembang. Uji hipotesis yang dilakukan oleh peneliti dalam penelitian ini yakni menggunakan teknik yang disebut dengan uji-t (t-test). Namun sebelum dilakukan uji hipotesis, penulis melakukan uji normalitas terlebih dahulu. Hal ini dilakukan bertujuan untuk mengetahui apakah data sampel berasal dari populasi yang berdistribusi normal serta berasal dari varians yang sama. Kriteria pengujian hipotesis dalam penelitian ini adalah:

Jika $t_{\text {hitung }}>\mathrm{t}_{\text {tabel }}$ maka Ho ditolak, Ha diterima

Jika $t_{\text {hitung }} \leq \mathrm{t}_{\text {tabel }}$ maka Ho diterima, Ha ditolak

Ho : Permainan bakiak tidak memiliki pengaruh terhadap perkembangan sosial anak usia 5-6 tahun kelompok B TK Nusa Indah Palembang.

Ha : Permainan bakiak memiliki pengaruh terhadap perkembangan sosial anak usia 56 tahun kelompok B di TK Nusa Indah Palembang.

Dengan kriteria pengujian hipotesis, yaitu jika thitung lebih besar dari $t_{\text {tabel }}$ dengan taraf signifikan $(\alpha)=6,1$ maka dapat disimpulkan bahwa Ha diterima, sebaliknya jika thitung lebih kecil dari $\mathrm{t}_{\text {tabel }}$ maka Ha ditolak.

Rancangan perlakuan dalam penelitian ini adalah mengetahui ada atau tidaknya pengaruh permainan bakiak terhadap perkembangan sosial anak kelompok B usia 5-6 tahun di TK Nusa Indah Palembang. Dalam penelitian ini yang digunakan adalah dua kelas, dimana 
untuk mengetahui ada atau tidaknya pengaruh perlakuan yang dilakukan. Adapun rancangan dalam penelitian ini adalah:

Tahap pemberian Tes Awal (Pretest) pada tahap ini kedua kelompok baik kelompok eksperimen maupun kelompok kontrol diberikan pretest berupa kegiatan bermain puzzle. Permainan puzzle dilakukan secara berkelompok dan dibagi menjadi empat kelompok. Guru menjelaskan dahulu peraturan dan cara menyusun puzzle sampai selesai. Peraturan permainan dalam setiap kelompok yaitu anak diminta untuk menyusun puzzle secara bergiliran sesuai urutannya, setiap anak diberikan waktu 30 detik untuk menyusun, lalu bergiliran lagi begitu seterusnya sampai batas waktu yang ditentukan, anak boleh membantu teman ketika mengalami kesulitan. Keseluruhan kelompok diberi waktu 5 menit untuk menyelesaikan. Antara keempat kelompok tersebut siapa yang paling cepat menyelesaikan maka itu yang akan menjadi pemenangnya. Tes ini dilakukan untuk membuktikan bahwa kelompok eksperimen dan kelompok kontrol memiliki kemampuan yang sama dalam perkembangan sosial, tes ini bertujuam untuk mengetahui keadaan awal perkembangan sosial anak sebelum diberikan perlakuan (treatment). Apabila hasil pretest menunjukkan hasil yang tidak signifikan, maka peneliti dapat melanjutkan ketahap selanjutnya yaitu pemberian perlakuan

Tahap Pemberian Perlakuan (Treatment) pada tahap ini peneliti memberikan perlakuan treatmentpadakelas eksperimen berupa kegiatan permainan bakiak untuk meningkatkan perkembangan sosial anak. Permainan bakiak adalah permainan yang mengutamakan kekompakan, kebersamaan dan saling membantu antara para peserta. Parapemain harus berjalan secara kompak untuk menjaga keseimbangan agar tidak terjatuh. Untuk melakukan permainan ini dibutuhkan antara lima sampai enam orang. Pemberian perlakuan ini direncanakan sebanyak 6 kali pertemuan dengan waktu 2 kali seminggu. Sedangkan kelas kontrol tidak diberi perlakuan.

Tahap Pemberian Tes Akhir (Posttets).

Dalam penelitian ini, teknik pengumpulan data yang digunakan adalah observasi dan dokumentasi.

HASIL DAN PEMBAHASAN

1. Hasil

a. Uji Normalitas Data 
Berdasarkan perhitungan yang di dapat untuk posttest $-0,23$, uji normalitas data yang diperoleh adalah dan pretest diperoleh $-0,03$. Harga tersebut terletak antara (-1) dan (1) sehingga dapat dikatakan bahwa data kedua kelas tersebut terdistribusi normal.

\section{b. Uji Homogenitas Data}

Hasil perhitungan uji homogenitas untuk $F_{\text {hitung }}<F_{\text {tabel }}$ atau $1,0<2,42$ ini berarti data dalam penelitian ini bersifat homogeny dan dapat dilanjutkan ke pengujian hipotesis.

\section{c. Uji Hipotesis}

Berdasarkan hasil perhitungan uji$\mathrm{t}$ nilai $t_{\text {hitung }}=6,1$ dengan demikian dapat disimpulkan bahwa $t_{\text {hitung }}>t_{\text {table }}$ atau 6,1> 2,42 maka $H_{0}$ ditolak dan $H_{a}$ diterima. Maka dari itu hipotesis penelitian ini, terdapat pengaruh permainan bakiak terhadap perkembangan sosial anak kelompok B (Usia 5-6 tahun) di TK Nusa Indah Palembang.

\section{Pembahasan}

Perkembangan sosial adalah proses belajar menyesuaikan diri dengan lingkungan untuk menentukan hubungan sosial manusia terhadap norma-norma kelompok, moral dan tradisi, dengan cara beriteraksi sehingga menjadi suatu kesatuan yang saling beradaptasi. Menurut
Yusuf (2015:122), perkembangan sosial anak merupakan pencapaian kematangan hubungan sosial. Dapat juga diartikan sebagai proses belajar untuk menyesuaikan diri terhadap norma-norma kelompok, moral dan tradisi, meleburkan diri menjadi suatu kesatuan yang saling berkomunikasi dan bekerja sama.

Berdasarkan hasil penelitian yang dilakukan peneliti bahwa permainan bakiak memiliki pengaruh terhadap perkembangan sosial anak usia dini kelompok B di TK Nusa Indah Palembang hal ini terbukti dari hasil peningkatan ratarata nilai pretest kelas eksperimen yaitu 43,5 ke hasil rata-rata nilai posttest kelas eksperimen yaitu 66,1. Dan dengan hasil uji-t yaitu nilai $t_{\text {hitung }}=6,1$ dan $t_{\text {table }}=2,42$ dapat disimpulkan bahwa $t_{\text {hitung }}>t_{\text {table }}$ atau 6,1> 2,42 maka $H_{0}$ ditolak dan $H_{a}$ diterima. Yang artinya terdapat pengaruh yang signifikan dari permainan bakiak terhadap perkembangan sosial anak usia dini kelompok B di TK Nusa Indah Palembang. Hal itu sejalan pada penelitian yang dilakukan oleh Eny Nur Hasanah, Wahono, Tri Kurniawati (2019) dengan judul "Pengaruh Sandal Bakiak Terhadap Keterampilan Sosial Anak Di TK S Melati Surabaya". Penelitian ini menggunakan jenis penelitian kuantitatif dengan desain one group pretest posttest karena hanya 
menggunakan satu kelas sebagai sampel penelitian dan adanya tahapan pretest, posttest sebagai proses pemerolehan data. Hasil analisis data memperoleh nilai $\mathrm{T}$ hitung 0 dan nilai $\mathrm{T}$ tabel 40 , karena $0<40$ maka hasil penelitian menyatakan bahwa terdapat pengaruh permainan sandal bakiak terhadap keterampilan sosial anak.

Melihat dari teori dan kajian terdahulu yang relevan di atas dengan hasil dari penelitian yang dilakukan oleh Gian Prantoro (2015), yang berjudul "Pengaruh Penggunaan Permainan Tradisional Bakiak Dan Engklek Terhadap Keterampilan Sosial Anak Usia Dini” Berdasarkan hasil penelitian menunjukkan bahwa Perbandingan dari nilai pre-test dan permainan tradisional bakiak diperoleh nilai terendah yaitu 23 pada post-test dan 17 pada pretest, sedangkan kan nilai tertinggi diperoleh nilai 29 pada post-test dan 22 pada pre-test. Hal ini membuktikan bahwa ada perbedaan pengaruh yang signifikan antara sebelum menggunakan permainan tradisional bakiak dan pada saat menggunakan permainan tradisional bakiak terhadap keterampilan sosial anak. Dari penilaian diatas digambarkan bahwa permainan tradisional bakiak menunjukkan perbedaan nilai yang signifikan disbanding dari nilai pre-test atau sebelum menggunakan permainan tradisional bakiak.

\section{KESIMPULAN DAN SARAN}

Berdasarkan hasil penelitian dan analisis data maka dapat disimpulkan bahwa Permainan bakiak dapat memberikan pengaruh terhadap perkembangan sosial anak usia dini kelompok B (Usia 5-6 tahun) di TK Nusa Indah palembang. Hal ini dapat dilihat dari perhitungan hipotesis dengan menggunakan uji-t diperoleh nilai $t_{\text {hitung }}=$ 6,1 dan $t_{\text {table }}=2,42$ dapat disimpulkan bahwa $t_{\text {hitung }}>t_{\text {table }}$ atau 6,1 > 2,42 maka $H_{0}$ ditolak dan $H_{a}$ diterima. Yang artinya terdapat pengaruh yang signifikan dari permainan bakiak terhadap perkembangan sosial anak usia dini kelompok B di TK Nusa Indah Palembang. Perkembangan sosial anak mengalami peningkatan setelah peneliti memberikan perlakuan (treatment) dengan menggunakan permainan bakiak selama 4 kali pertemuan. Dimulai dari tanggal 8 Oktober2019 sampai dengan tanggal 11 Oktober 2019.

Berdasarkan kesimpulan yang telah dipaparkan, maka peneliti memberikan saran untuk:

1. Sekolah

Permainan bakiak diharapkan dapat dijadikan sebagai sebuah strategi dalam 
pembelajaran yang dapat memotivasi anak untuk melatih perkemabangan anak dan sebagai salah satu alternatif untuk meningkatkan mutu pembelajaran yang ada di sekolah.

\section{Guru}

Memberikan pengalaman kepada guru dalam proses pembelajaran dengan menggunakan permainan bakiak terhadap peningkatan perkembangan sosial pada anak.

\section{Orang Tua}

Orang tua diharapkan menyediakan waktu luang untuk berinteraksi pada anak melalui permainan bakiak sehingga dapat membantu mengoptimalkan perkembangan sosial pada anak.

\section{DAFTAR PUSTAKA}

Desmita, 2015. Psikologi Perkembangan. Bandung: PT REMAJA ROSDAK t 2o ARYA, hal. 141

Eci FE, 2017. Buku Pintar Olahraga Dan Permainan Tradisional. Jogjakarta: LAKSANA, hal. 44-45

Eny Nur Hasanah, dkk. 2019. Pengaruh Sandal Bakiak Terhadapketerampilan Sosial Anak Di TK Melati Surabaya. Universitas Muhammadiyah Surabaya. (Volume 5. No. 1)

Esnoesanoesi dalam Maria Hdayanti . 2013. Peningkatan Kemampuan Motorik Kasar Anak Melalui Permainan Bakiak. PAUD Pps. Universitas Negri Jakarta (Volume 7. No 1)
Idad Suhada, 2016. Psikologi Perkembangan Anak Usia Dini (Raudathul Athfal). Bandung: PT REMAJA ROSDAKARYA, hal 103-104

Gian Prantor, 2015. Pengaruh Penggunaan Permainan Traadisional Bakiak Dan Engklek Terhadap Keterampilan Sosial Anak Usia Dini. Universitas Negrim Yogyakarta

John W. Santrock. 2007. Perkembangan Anak. Erlangga: PT GELORA AKSARA PRATAMA, hal. 216

Novi Mulyani, 2016. Dasar-Dasar Pendidikan Anak Usia Dini. Yogyakarta: KALIMEDIA, hal. 111

Sri Mulyani, 2013. 45 Permainan Tradisional Anak Indonesia. Yogyakarta: LANGENSARI PUBLISHING, hal. 9-11

Sugiyono, 2017. Metode Penelitian Pendidikan, Pendekatan Kuantitatif, Kualitatif, dan $R \& D$. Bandung: ALFABETA, hal 75

Suyadi dan Ulfah, 2015. Konsep Dasar Paud. Bandung: PT REMAJA ROSDAKARYA, hal. 34

Syamsu Yusuf, 2015. Psikologi Perkembangan Anak Dan Remaja. Bandung: PT REMAJA ROSDAKARYA, hal. 122

Zulfauzia, dkk. 2016. Peningkatan Kemampuan Motorik Kasar Melalui Permainan Kooperatif Bakiak Raksasa Pada Anak Usia 56 Tahun. Universitas Tanjungpura Pontianak (Volume, 5, No 1) 
PERNIK Jurnal PAUD, VOL 2 NO.1 September 2019 